\title{
Correction to: CPR with restricted patient access using alternative rescuer positions: a randomised cross-over manikin study simulating the CPR scenario after avalanche burial
}

\author{
Bernd Wallner ${ }^{1,2^{*}} \mathbb{0}$, Luca Moroder ${ }^{3}$, Hannah Salchner ${ }^{1}$, Peter Mair ${ }^{1}$, Stefanie Wallner ${ }^{1}$, Gabriel Putzer
} Giacomo Strapazzon ${ }^{2}$, Markus Falk ${ }^{2,4}$ and Hermann Brugger ${ }^{2}$

\section{Correction to:Scand J Trauma Resusc Emerg Med (2021) 29:129} https://doi.org/10.1186/s13049-021-00944-9

Following the publication of the original article [1], the authors requested to amend the "Acknowledgements" and "Funding" sections of their article, to acknowledge the financial support received by the Autonomous Province of Bozen/Bolzano.

The "Acknowledgements" section has now been updated to include the following statement: "The authors thank the Department of Innovation, Research, University and Museums of the Autonomous Province of Bozen/Bolzano for covering the Open Access publication costs".

In the "Funding" section the sentence "There was no other funding supporting this manuscript" has been replaced by the sentence "The Department of Innovation, Research, University and Museums of the Autonomous Province of Bozen/Bolzano covered the Open Access publication costs".

The original article can be found online at https://doi.org/10.1186/s13049021-00944-9.

\footnotetext{
*Correspondence: bernd.wallner@i-med.ac.at

1 Department of Anaesthesiology and Intensive Care Medicine, Innsbruck

Medical University Hospital, Medical University of Innsbruck, Anichstrasse

35, 6020 Innsbruck, Austria

Full list of author information is available at the end of the article
}

The original article has already been corrected as above.

\begin{abstract}
Author details
${ }^{1}$ Department of Anaesthesiology and Intensive Care Medicine, Innsbruck Medical University Hospital, Medical University of Innsbruck, Anichstrasse 35 6020 Innsbruck, Austria. ${ }^{2}$ Institute of Mountain Emergency Medicine, Eurac Research, Viale Druso 1, 39100 Bolzano, Italy. ${ }^{3}$ Department of Anaesthesiology and Critical Care Medicine, Hospital of Bolzano, Lorenz Böhler Strasse 5, 39100 Bolzano, Italy. ${ }^{4}$ eScience, Sonnenstrasse 11, 39031 Bruneck, Italy.
\end{abstract}

Published online: 29 September 2021

Reference

1. Wallner, et al. CPR with restricted patient access using alternative rescuer positions: a randomised cross-over manikin study simulating the CPR scenario after avalanche burial. Scand J Trauma Resusc Emerg Med. (2021);29:129. https://doi.org/10.1186/s13049-021-00944-9.

\section{Publisher's Note}

Springer Nature remains neutral with regard to jurisdictional claims in published maps and institutional affiliations.

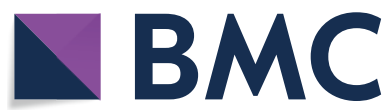

(c) The Author(s) 2021. Open Access This article is licensed under a Creative Commons Attribution 4.0 International License, which permits use, sharing, adaptation, distribution and reproduction in any medium or format, as long as you give appropriate credit to the original author(s) and the source, provide a link to the Creative Commons licence, and indicate if changes were made. The images or other third party material in this article are included in the article's Creative Commons licence, unless indicated otherwise in a credit line to the material. If material is not included in the article's Creative Commons licence and your intended use is not permitted by statutory regulation or exceeds the permitted use, you will need to obtain permission directly from the copyright holder. To view a copy of this licence, visit http://creativecommons.org/licenses/by/4.0/. The Creative Commons Public Domain Dedication waiver (http://creativecommons.org/publicdomain/zero/1.0/) applies to the data made available in this article, unless otherwise stated in a credit line to the data. 